\title{
Joint energy and water management scheme for water supply systems in Romania
}

\author{
Aida Delcea ${ }^{1, *}$, Ioan Bitir-Istrate ${ }^{1}$, Roxana Pătrașcu ${ }^{1}$, and Cristian Gheorghiu ${ }^{1}$ \\ ${ }^{1}$ University "Politehnica" of Bucharest, Faculty of Power Engineering, 313 Spl. Independenței, Bucharest, Romania
}

\begin{abstract}
Keeping in mind the short-term and long-term aims of cost depletion and sustainable development respectively, a joint water and energy management scheme for water supply systems that leads to reduced energy losses is proposed. For water utilities, drinkable water's treatment and pumping and wastewater treatment are the main energy-consuming processes and a proportional part of this energy is wasted with non-revenue water. In Romania, these losses can reach critical levels so highlighting them becomes a crucial aspect in assessing the system's efficiency. This paper presents a scheme that combines energy audit and water balance techniques that can become a tool for both energy auditors and managers, by allowing the quantification of embedded energy of water losses. The methodology is adapted for the conditions in Romania, where data collection and processing is mainly done manually.
\end{abstract}

\section{Introduction}

Energy production needs water and water supply needs energy. This statement, in its various forms, is encountered more and more often in the research and policy making communities as efforts converge towards a better understanding of the water-energy nexus and its practical implementation, considering the rapidly growing demand for both resources. Previous studies focused either on water for energy or energy for water side of the nexus, either had a holistic approach for quantitatively and qualitatively describe the water-energy interlinkages [1].

Regarding the water side of the nexus, it is estimated that energy consumption for treatment and pumping of drinking and industrial water accounts for $2-3 \%$ of the world's total energy consumption [2] or somewhere around 120 Mtoe (million tonnes of oil equivalent) [3]. From this energy, 60\% represents electricity and it corresponds to $4 \%$ of total electricity consumption worldwide [3]. For water companies, energy costs can go as high as $30-40 \%$ of total costs, especially in areas where freshwater resources are scarce [4], so reducing the energy bill must become a priority.

Saving water and energy in water utilities not only has a benefic impact from technical and economical points of view, but also from a societal perspective (lower living costs can improve the quality of life while more people can have access to drinking water considering the same quantity of exploited freshwater) and an environmental one (stress on climate change and freshwater availability can be reduced) [5].

This paper presents a management/auditing scheme whose main aim is quantifying the energy lost with water losses in a water supply system. The case-study depicted and discussed is based on data from two regional privately-operated water utilities in Romania. The first step of the proposed methodology aims to emphasize the energy consumption in drinking water processing which can be directly linked to all types on non-revenue water from all other energy consumption a water company's energy bill entails. The second step focuses on the actual quantification of energy lost and its impact on the efficiency of the company based on energy auditing, water balance and life cycle assessment principles.

\section{Context and opportunities}

\subsection{Present state of the water-energy nexus}

Many articles have been published recently in the waterenergy nexus topic. Interlinkages between water and energy arise in both directions: water is needed in all stages of energy production, while energy is required for a wide range on water related processes. While there is an abundance of water worldwide, less than $1 \%$ is actually proper for human consumption as most glaciers are made of most of the available freshwater [3].

\footnotetext{
* Corresponding author: aida.delcea@gmail.com
} 


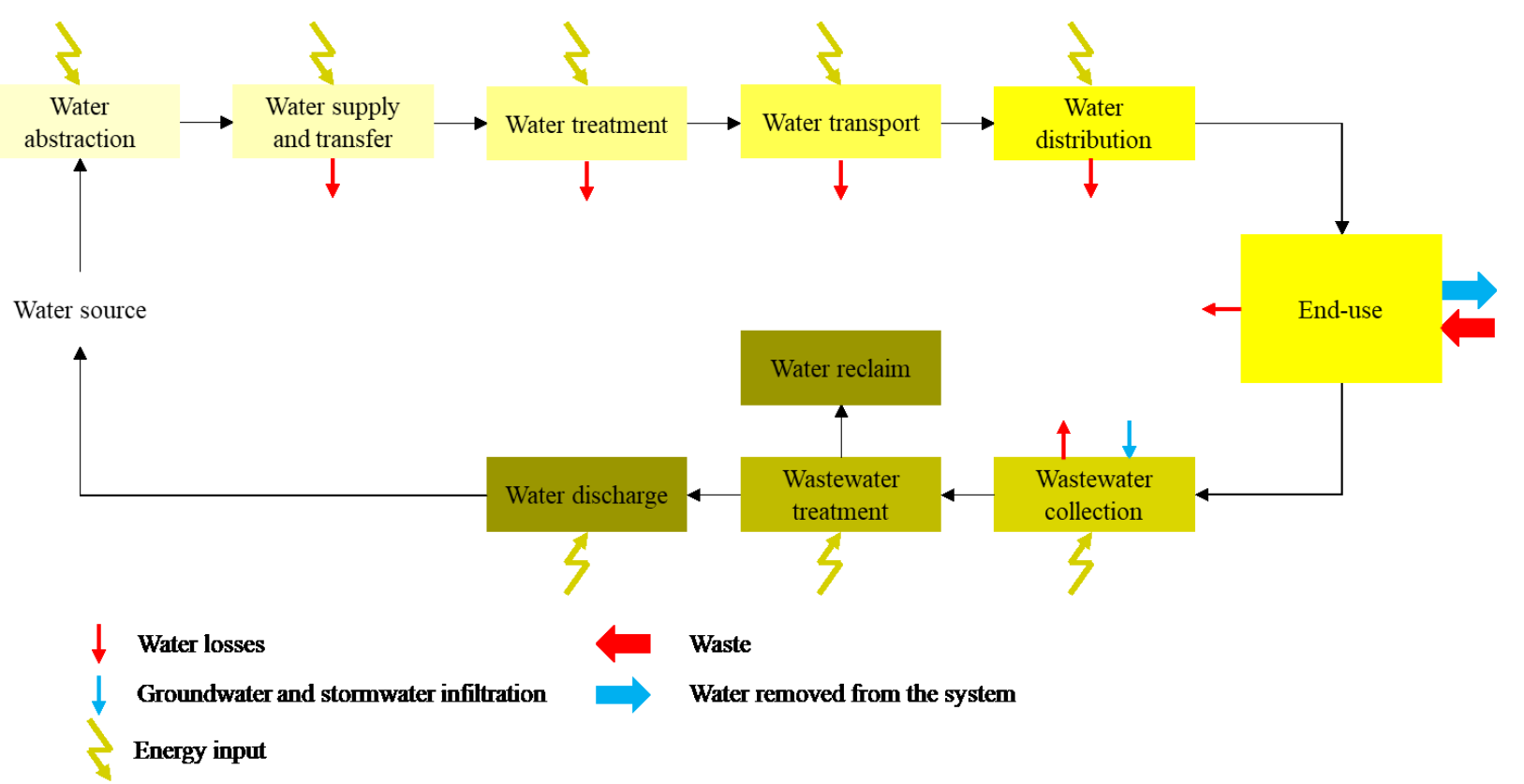

Fig. 1. Processes of water sector. Source: Adapted from [3].

Population growth and urbanization, alongside the increase in water necessities for energy production put a high stress on the already overly-exploited water resources. On the other hand, energy demand increase and the use of fossil-fuel threaten the climate and the environment. As a shift towards more water-intensive energy and energy-intensive water is predicted to occur in the next 25 years, the need for integrated water-energy policies and infrastructures arises [3].

Water needed for human activities goes through all or some of the following processes, depicted in figure 1 [6]:

- raw water abstraction,

- $\quad$ raw water supply and transfer,

- water treatment,

- clear water transport,

- clear water distribution,

- $\quad$ end-use,
- wastewater collection,

- wastewater treatment,

- water discharge or reclamation.

Water transport and distribution are technically the same process in which the water is trasfered from one point to another through a network usually comprised of pipes, storage and pumps. However, the transport lines have high capacities and usually connect a treatment plant with some central storage in the distribution areas, while distribution lines have smaller capacities and supply water directly to the users [6].

At the end-use, the waste input is seen as substances other than water that are disposed in the sewage system. The water removed from the system represent that type of consumption that doesn't involve the water to return in the sewage system, such as water gardening or irrigation.

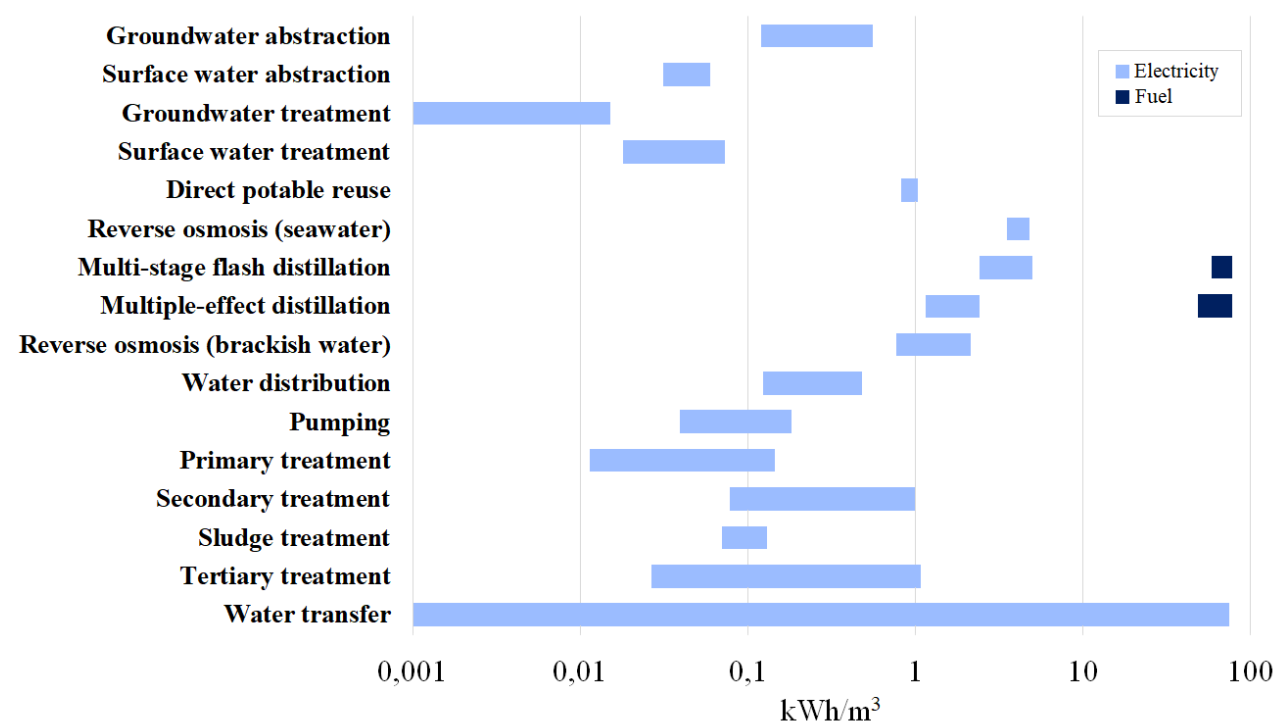

Fig. 2. Energy use for various water processes in the water sector. Source: Adapted from [3]. 
As depicted in figure 1, all the above-mentioned processes require energy. The energy demand varies with water quality, distance from source to consumer, topography, but also with water losses and inefficiencies [3]. A benchmark for energy consumption by each process in the water sector was done by the IEA in the Water-Energy Nexus Excerpt of the World Energy Outlook 2016 [3] and is illustrated in figure 2. Wastewater treatment, desalinization and water distribution are the main electricity consuming processes, while water transfer can reach high rates in areas with scarce water resources. However, both groundwater and surface water imply important energy consumptions as abstraction is more energy-intensive for groundwater while treatment is more energy-intensive for surface water [3].

On the other hand, water losses are linked to the characteristics of the water supply systems (like age and topography), but also theft and innacurate metering can be accounted for this losses [3]. Van den Berg also found that the amount of water losses can be linked to population density, with urban areas generally showing greater inefficiencies [7]. In the European Union, volumetric losses reach about 13 bilion $\mathrm{m}^{3}$ anually $(24 \%$ of total abstracted water) compared to the most developed countries like Japan or Denmark where only $6 \%$ of total abstracted water is lost in the processes [3].

The water-energy nexus in water supply systems has been investigated from both energy audits and life cycle assessment perspectives [8], however no integrated approach was identified by the authors. Also, quatification of the energy lost with water losses was done by Cabrera et al [9], Mamade et al [5], but they did not consider the energy used in the clear water treatment phase, although it can be considered as a direct energy input in the water supply system. Another impediment encountered in other methods was the comprehensive amount of data needed to study various aspects of the nexus like hydraulic models or detailed topographic information, making the assessment of energy efficiency rather difficult.

\subsection{Romania's water supply status}

Romania is a low-income country situated in the southeastern part of geographical Central Europe, with a population of 19.7 million people, $53.7 \%$ of whom reside in urban areas. The three major levels of its relief are proportional (31\% for the Carpathian Mountains, 36\% for the Sub-Carpathians, hills and plateaus and 33\% for plains, meadows and the Danube Delta), also showing a concentric display [10]. In terms of climate, Romania is a temperate-continental of transition country with oceanic, Mediterranean and continental-excessive influences [10]. Multiannual average temperatures vary from $-2.5^{\circ} \mathrm{C}$ to $11.6^{\circ} \mathrm{C}$ and yearly precipitation can be found between 350 $\mathrm{mm}-1500 \mathrm{~mm}$ depending on the region [10]. All of this leads to a vast network of available freshwater resources where both surface water and groundwater are exploited. Also, about $61.25 \%$ of total length of monitored water bodies are considered to have a "very good" and "good" status in terms of water quality [10].

The regulatory agency in the water sector in Romania is "Autoritatea Națională de Reglementare pentru Serviciile Comunitare de Utilităţi Publice" - "National Romanian Regulator for Public Services" (ANRSC). As there was no more recent data available at a national level, a report published by ANRSC states that in 2011 a total number of 1021 entities were administrating water services [11], including mostly private 44 regional operators who accounted for $86,3 \%$ of the market share. The utilities usually manage all the existing stages of drinking water cycle, from abstraction, potable water treatment, transport and distribution to the collection, treatment and discharge of wastewater.

The authorized billed consumption for the regional operators summed a total of 617.510 million $\mathrm{m}^{3}$ from 1135.142 million $\mathrm{m}^{3}$ of total input volume, meaning that only $55 \%$ of the treated water is distributed to the consumers (not including the authorized unbilled consumption) [11]. Figure 3 depicts the authorized billed water consumption and unbilled water consumption per each of the regional utilities.

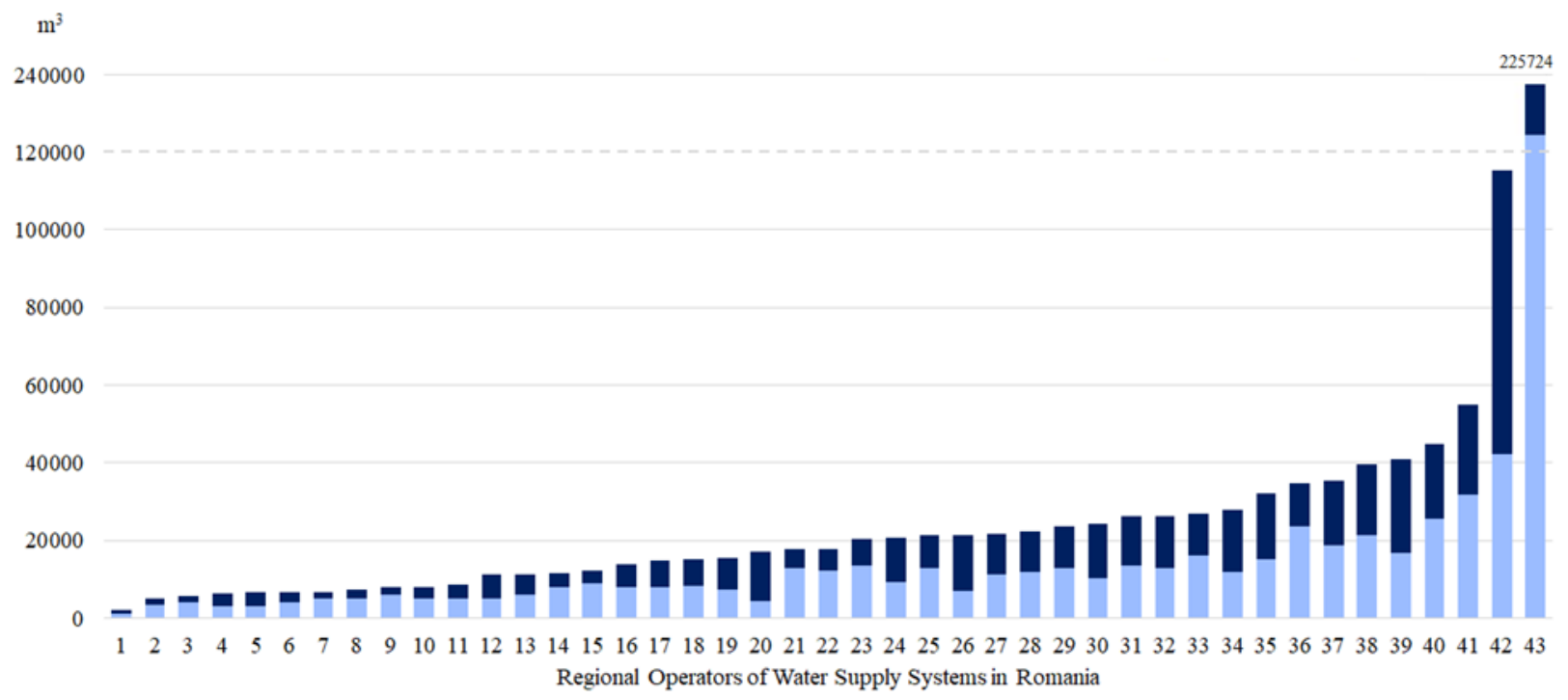

Fig. 3. Authorized billed water consumption and unbilled water consumption in Romania, by regional operator. Source: [12]. 
In $2011,12.089$ million people $(64 \%$ of total population) were connected to centralized water supply systems while only 9.319 million people (49\%) were connected to the centralized wastewater systems. From an administrative-territorial point of view, 318 (99.4\%) urban areas and 1609 rural areas $(54.5 \%)$ had access to the centralized water systems [12]. However, due to the implementation of funding schemes such as POS Mediu and POIM, the number of rural areas served by centralized systems increased to 1971 (68.92\%) in 2016 and this trend is predicted to continue [13].

\subsection{Romania's energy efficiency in water sector}

Energy audit and energy management are viewed as tools to assess and address energy efficiency. While energy management mainly relates to a detailed energy strategy of a specific company and its implementation, energy auditing's main objectives are [14]:

- $\quad$ establishing the type and order of magnitude of the energy flows/consumptions;

- creating an inventory of energy resources, transformation steps and consumption for the analyzed contour;

- forecasting the tendency of future energy consumptions;

- identifying the most energy intensive subsystems or energy account centers;

- $\quad$ assessing the energy efficiency of the analyzed contour or for each of the energy account centers;

- proposal of solutions for increasing energy efficiency.

However, due to the wide range of available industries that a single auditor encounters, specific measures for energy efficiency increase become the hardest to achieve and propose properly.

In Romania, the regulatory agency in the energy sector and energy efficiency policies implementation is "Autoritatea Națională de Reglementare în domeniul Energiei" - "National Energy Regulatory Agency" (ANRE). According to ANRE, in 2016 water distribution and waste management activities accounted for $0.895 \%$ (10702 toe) of total energy consumptions and $10.76 \%$ of total production costs for this sector. However, this percentage applies only for a reported number of 22 companies in this field that consume over 1000 toe, so it does not include all the regional operators and none of the local ones. From 75 reported energy efficiency measures, the most common are pump replacing, GPS monitoring for large vehicles and modernization of facilities related to general services [15], but no mention of water losses' management was encountered as a solution.

Considering all the above mentioned, the opportunity to quantify energy lost with water losses directly used in all stages of water supply arose as part of an integrated water-energy management. Due to the high percentage of water losses in regional water supply systems in Romania (45\% on average) [11] compared to the most developed countries like Denmark and Japan (6\% on average) [3], it is expected that important energy savings could be achieved by encouraging this approach.

\section{Methodology}

The first step of the methodology proposed seeks to separate the energy consumptions by the types of consumers, in order to assess the efficiency of each sector. Figure 4 shows the main three activities that require energy in a water company: drinking water processing, wastewater processing and auxiliary services. Due to the use of different energy resources, all consumptions should previously be normalized (in this case, the values for different consumptions will be converted to tonnes of oil equivalent - toe) for this analysis' purposes. Considering that the main activities for a water company are drinking water and wastewater processing, a third energy account center was identified as auxiliary services where energy such as that used for heating and lighting of buildings, transportation for administrative and operational purposes could be included.

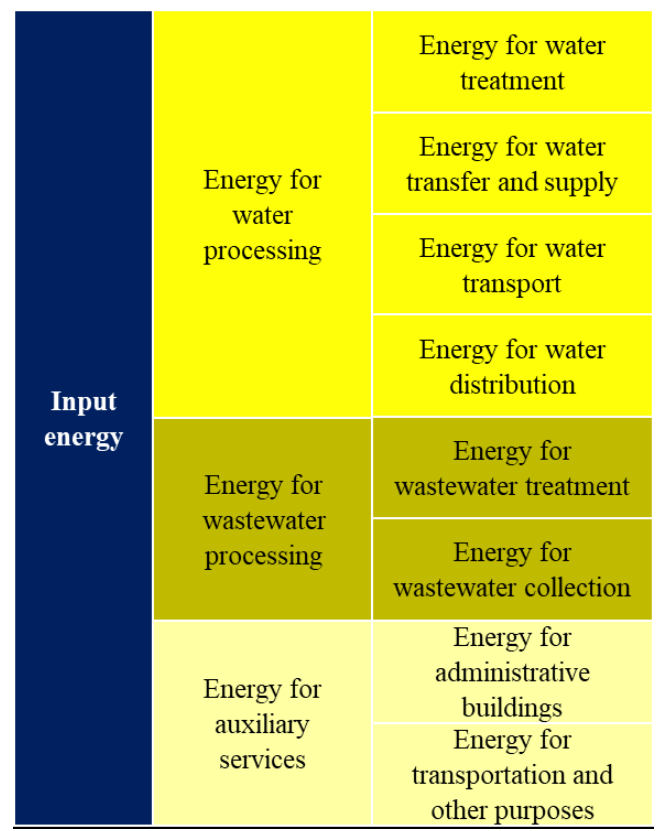

Fig. 4. Types of energy consumptions in water utilities.

Therefore, the total energy input for the water utility will be:

$$
E_{i n}^{W U}=E_{i n}^{W P}+E_{i n}^{W W P}+E_{i n}^{A S}
$$

where the notations used in equation (1) are as following: $E_{i n}^{W U}$ annual total energy input

$E_{i n}^{W P}$ annual energy input for drinking water processing

$E_{i n}^{W W P}$ annual energy input for wastewater processing

$E_{i n}^{A S}$ annual energy input for auxiliary services

To establish an inventory of energy consumptions, specific energy consumption per volume of water sold (D4) [16] will be calculated for each account center with the equation:

$$
D 4^{j}=\frac{E^{j}}{W_{A B C}}
$$

where the terms used in equation (2) are as following:

$E^{j} \quad$ annual energy consumed in account center $j$,

$W_{A B C}$ annual volume of authorized billed water consumption 
The second step focuses on drinkable water processing, where a direct link between energy consumptions and water losses can be identified and quantified, by using the principles of life cycle assessment, energy audit and IWA water balance [17]. As figure 1 depicts by using the gradual coloring, the closer the potable water gets to its end use, the more embedded energy it has, meaning that more energy was used to get it to that quality and point in the system. Hence, considering a node $i$ in the supply system where water losses occur, the energy lost with it can be approximated with equation (3).

$$
E_{W L}^{i}=V_{W L}^{i} \cdot \sum_{k=1}^{i} e_{i n}^{k}
$$

where the terms used in equation (2) are as following: $E_{W L}^{i} \quad$ energy lost with water losses in node $i$

$V_{W L}^{i} \quad$ volume of water losses in node $i$

$e_{i n}^{k} \quad$ energy consumed for $1 \mathrm{~m}^{3}$ of water for process $k$, upstream process $i$
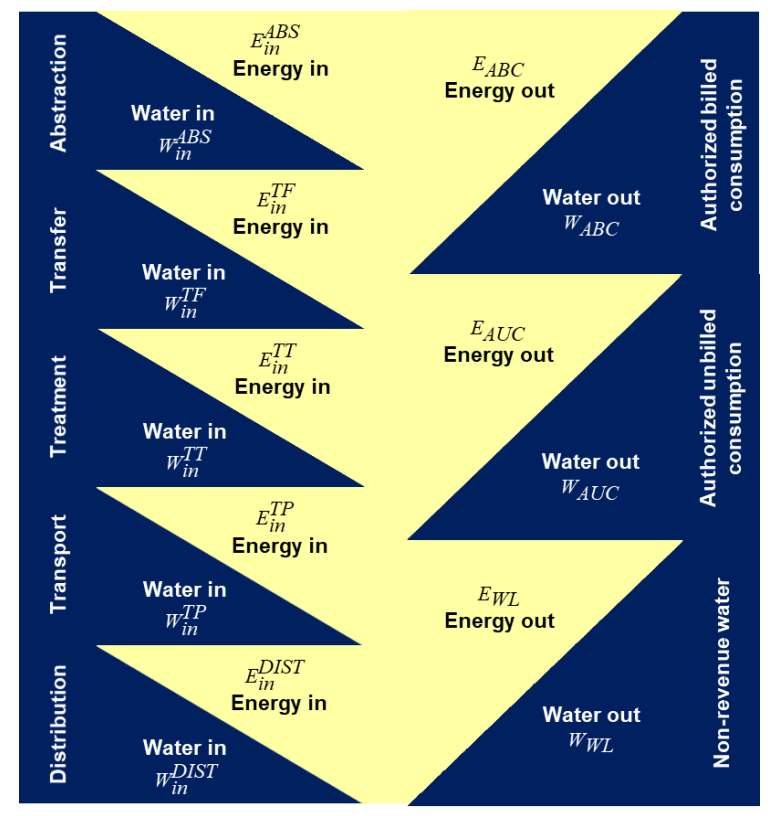

Fig. 5. Water-energy balance.

The equation (3) considers only the shaft input energy, as redesigning the topology of the water supply system as a measure of improving energy efficiency does not make a purpose of this paper. Also, the embedded energy considered is only the one consumed directly in each process by the water utility (for example, energy needed for pumping in different stages of water treatment is considered, while energy needed to transport different chemical compounds used in treatment processes from their production site to the water treatment facility is not).

In terms of energy auditing, the equation (3) can be adapted to quantify the energy lost with water losses annually. The processes depicted in figure 4 for drinking water supply side can be assimilated to nodes with corresponding energy inputs and water losses (or consumptions in case of water treatment) as in equation (4).

$$
E_{W L}^{i}=W_{W L}^{i} \cdot \sum_{k=1}^{i} \frac{E_{i n}^{k}}{W_{i n}^{k}}
$$

where the notations used in equation (4) are as following: $W_{W L}^{i}$ annual volume of water losses in water process $i$ $E_{\text {in }}^{k} \quad$ energy input in water process $k$

$W_{i n}^{k} \quad$ annual volume of water supplied in the process $k$ The energy lost annually with water losses will then be represented by the sum of energy lost with non-revenue water in each process, depicted by equation (5).

$$
E_{W L}=\sum_{i=1}^{n} E_{W L}^{i}
$$

where $n$ is the total number of energy consuming processes water must go through, to reach final billed authorized consumption.

Special attention should be addressed to authorized unbilled consumptions (AUC) which usually represent water for technological and internal consumptions such as filter washing in water treatment facilities and tanks and pipes cleaning in distribution grids [18]. Quantification of these consumptions reveals the efficiency of maintenance and operation of water supply systems. However, they cannot be considered losses but rather volumes of water necessary in the process. The embedded energy attributed to them $\left(E_{A U C}\right)$ can be calculated the same way as the energy lost with water losses:

$$
\begin{gathered}
E_{A U C}^{i}=W_{A U C}^{i} \cdot \sum_{k=1}^{i} \frac{E_{i n}^{k}}{W_{i n}^{k}} \\
E_{A U C}=\sum_{i=1}^{n} E_{A U C}^{i}
\end{gathered}
$$

Energy associated with the authorized billed consumption (ABC) calculated with equation (8) will encompass the useful energy, but also the surplus energy and the energy dissipated in the system (i.e. energy lost due to pump inefficiencies or in pressure valves) [5],[9].

$$
E_{A B C}=\sum_{\mathrm{i}=1}^{\mathrm{n}} E_{i n}^{i}-E_{W L}-E_{A U C}
$$

\section{Case-study}

The case-study is based on real data from two water utilities in Romania, usually used in both water balances or energy audits. Table 1 shows an inventory of the energy resources used by the two water companies for a period of one year and Table 2 contains data about the yearly volumes of abstracted freshwater, billed drinking water and billed wastewater for both water companies.

The first water utility (WU1) encompasses an entire city and the distribution system attributed to it. For this system, clear water goes through the following processes: 
Table 1. Energy consumptions by type of resource for WU1 and WU2.

\begin{tabular}{|c|c|c|c|c|c|c|c|}
\hline & Electricity & Natural gas & Petrol & Diesel & LPG & Biomass & Biogas \\
\cline { 2 - 7 } & $\mathrm{MWh}_{\mathrm{e}}$ & $10^{3} \mathrm{Nm}^{3}$ & tons & tons & tons & tons & $10^{3} \cdot \mathrm{Nm}^{3}$ \\
\hline WU1 & 10888 & 40.05 & 29.10 & 97.70 & 8.52 & - & 56.82 \\
\hline WU2 & 9722 & 137.24 & 30.08 & 309.42 & - & 361.52 & 198.70 \\
\hline
\end{tabular}

groundwater abstraction and transfer, treatment and distribution. Water treatment consists only of chlorination and water supply and distribution are almost entirely ensured by pumps. Wastewater is collected and then treated in a single facility. Afterwards, treated wastewater is discharged.

Table 2. Water and wastewater balance input data $\left(10^{3} \cdot \mathrm{m}^{3}\right)$.

\begin{tabular}{|c|c|c|c|}
\hline $10^{3} \cdot \mathrm{m}^{3}$ & $\begin{array}{c}\text { Abstracted } \\
\text { water }\end{array}$ & $\begin{array}{c}\text { Billed } \\
\text { water }\end{array}$ & $\begin{array}{c}\text { Billed } \\
\text { wastewater }\end{array}$ \\
\hline WU1 & 10642 & 7795 & 11351 \\
\hline WU2 & 20028 & 13247 & 8442 \\
\hline
\end{tabular}

The second water utility (WU2) administers a big, regional water supply system which supplies about $80 \%$ of the existing customers in the region, but also some smaller local supply systems. The main water source consists of an artificial lake. Abstracted surface water goes through coagulation, filtration, sedimentation, filtration and disinfection processes in a nearby treatment plant. The obtained clear water is transported gravitationally to the distribution systems of most towns and villages in the county. Wastewater is collected and treated in multiple treatment facilities, and then discharged.

To assess the results according to the first step of the proposed methodology, the following statements are considered for the end-use of these energy resources:

- Energy losses occurring in the analyzed contour are not considered at this stage,

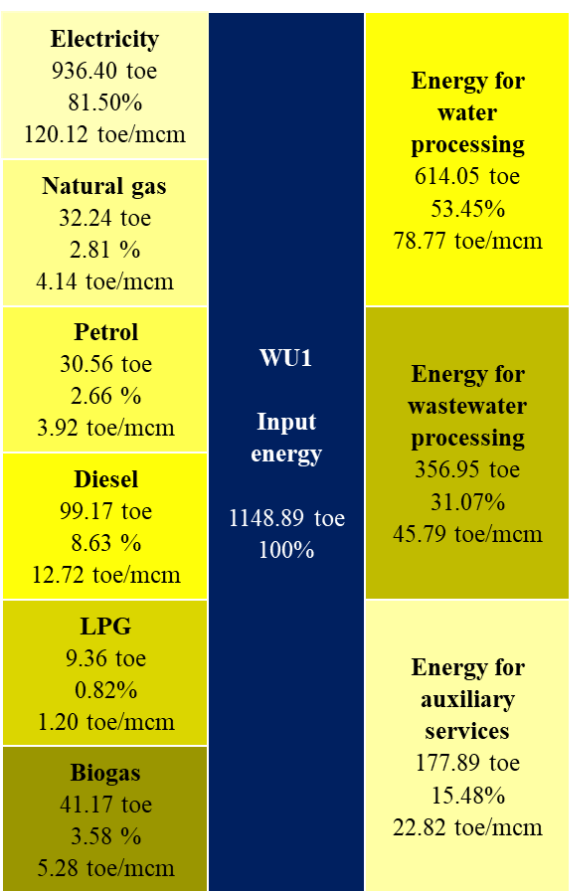

- Water and wastewater processing consume only electricity (as fuels are used just for auxiliary power generators in case of blackouts),

- Electricity consumed by computers for monitoring the systems' parameters are part of the energy consumed in the primary processes,

- Electricity for lighting and other administrative uses account for $0.5 \%-3 \%$ of total electricity demand,

- Natural gas and biomass are used only for heating spaces,

- Biogas, as a secondary product of wastewater treatment, is consumed in CHP (combined heat and power) plants to reduce other resources consumptions in the process,

- Liquid fuels (petrol, diesel, LPG) are only consumed by vehicles,

- Coefficients used in consumption normalization (conversion to toe) are presented in Table 3.

Table 3. Coefficients used in normalization of energy consumptions

\begin{tabular}{|c|c|}
\hline $\begin{array}{c}\text { Type of consumed } \\
\text { energy }\end{array}$ & $\begin{array}{c}\text { Conversion } \\
\text { coefficient }\end{array}$ \\
\hline Electricity & 0.086 toe $/ \mathrm{MWh}$ \\
Natural gas & 0.805 toe $/ 10^{3} \cdot \mathrm{Nm}^{3}$ \\
Petrol & 1.05 toe $/$ tons \\
Diesel & 1.015 toe $/$ tons \\
LPG & 1.099 toe $/$ tons \\
Biomass & 0.075 toe $/$ tons \\
Biogas & 0.7245 toe $/ 10^{3} \cdot \mathrm{Nm}^{3}$ \\
\hline
\end{tabular}

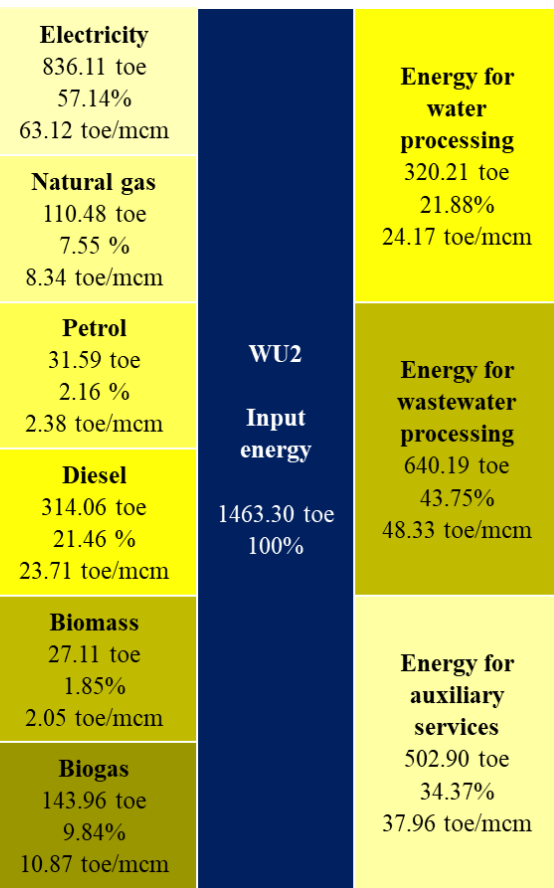

Fig. 6. Energy balance scheme - All WU1 and WU2 annual averaged consumptions. 
Results for both water companies are shown in Figure 6. Specific energy consumptions (D4) were also calculated for each type of energy resource and for each considered account center.

Calculated data showed that water processing is the most energy intensive activity for WU1, accounting for more than half of all energy consumed by the water company. Wastewater processing accounts for $31.07 \%$ of total energy consumptions while auxiliary services are responsible for nearly half of that. Hence, in terms of prioritization of energy efficiency action plan, processes related to raw and clear water part of the water cycle depicted in figure 1 should be analyzed in detail.

Compared to WU2, WU1's specific consumption for water processing is almost three times higher (78.77 toe $/ \mathrm{mcm}$ compared to 24.17 toe $/ \mathrm{mcm}$ ). However, these results were somewhat expected, as WU2 ensures the transportation and part of the water distribution gravitationally, while WU1's abstraction and distribution processes are ensured mostly by pumps. Specific consumption associated with wastewater processing is similar for the two water companies $(45.79$ toe $/ \mathrm{mcm}$ for WU1 compared and 48.33 toe/mcm for WU2). Auxiliary services are more energy intensive for WU2 (3.96 toe $/ \mathrm{mcm}$ ) compared to WU1 (22.82 toe $/ \mathrm{mcm})$.

The results obtained for WU2 show that wastewater processing is the most energy intensive activity, accounting for $43.75 \%$ of all energy consumptions. However, in terms of prioritization of energy efficiency measures, special attention should be addressed to auxiliary services which have a $34.37 \%$ share of total energy consumptions with 37.96 tonnes of oil equivalent consumed for one million of water sold, which is significantly more than water processing (at $21.88 \%$ of total energy consumptions).

For the second step of the proposed scheme, only energy inputs associated with water processing were considered (energy for water processing). For WU1, clear water transport is neglected because the distribution tanks are in the same facilities as the treatment equipment. For WU2, raw water supply is neglected because the water
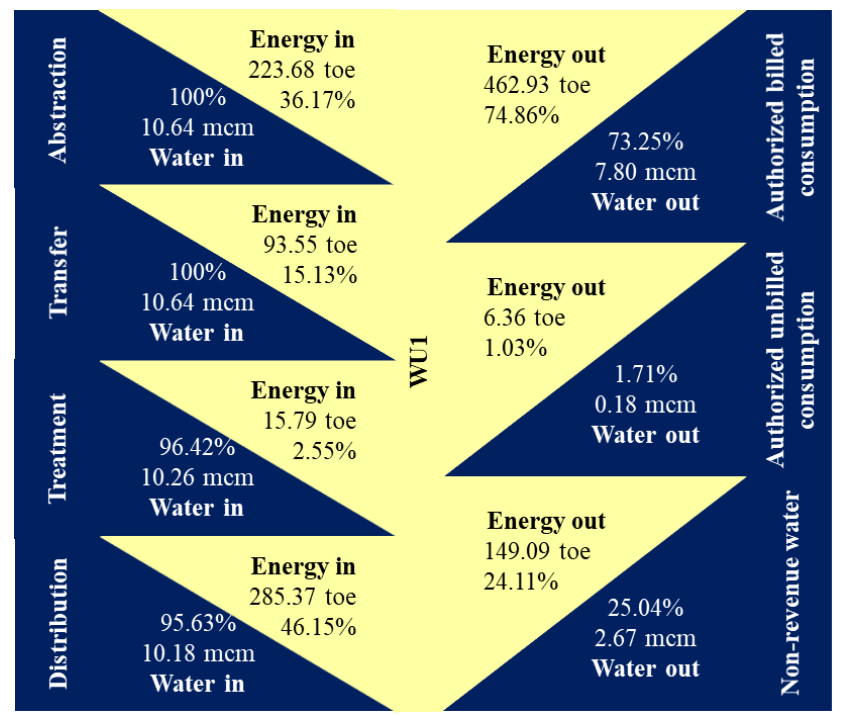

abstraction is located very close to the treatment facility and no water losses were detected for this stage. Data was estimated where there was no information available based either on values from the same water companies but from other operational years, either on values from other water utilities with similar water supply system's characteristics.

Figure 7 illustrates the results obtained for the two water utilities, as an average for the three years, both in absolute (toe for energy consumptions and $\mathrm{mcm}-$ million cubic meters for water volumes) and relative ( $\%$ of total) values. Values for specific energy lost with non-revenue water and authorized unbilled consumptions in all analyzed processes were also calculated for comparison reasons and are shown in Table 4.

Table 4. Specific embedded energy lost with water losses/consumptions (tep/mcm).

\begin{tabular}{|l|c|c|c|c|}
\hline & Transfer & Treatment & Transport & Distribution \\
\hline WU1 & 29.808 & 31.347 & - & 59.387 \\
\hline WU2 & - & 11.232 & 11.491 & 17.475 \\
\hline
\end{tabular}

Figure 7 shows that an important share of total input energy is lost with water losses for both water companies. For WU1, 149.09 toe ( $24.11 \%$ of total energy input) is lost with water losses, while 83.51 toe $(25.47 \%$ of total energy input) is lost with water losses on WU2. The energy losses are heavily dependent on the magnitude of water losses $(25.04 \%$ of total input water for WU1 and $28.31 \%$ of total input water for WU2).

Also, embedded energy lost with water losses is highly dependent on the point in the system where losses occur. As Table 4 depicted for WU1, specific embedded energy lost with water losses in the distribution system (59.387 toe $/ \mathrm{mcm}$ ) is almost two times higher than the specific embedded energy lost with water losses in the transfer system (29.808 toe/mcm). For WU2, specific embedded energy lost with water losses increases with about $50 \%$ in the distribution systems $(17.475$ toe $/ \mathrm{mcm})$ compared to the specific energy lost in the transport system (11.232 toe $/ \mathrm{mcm})$.

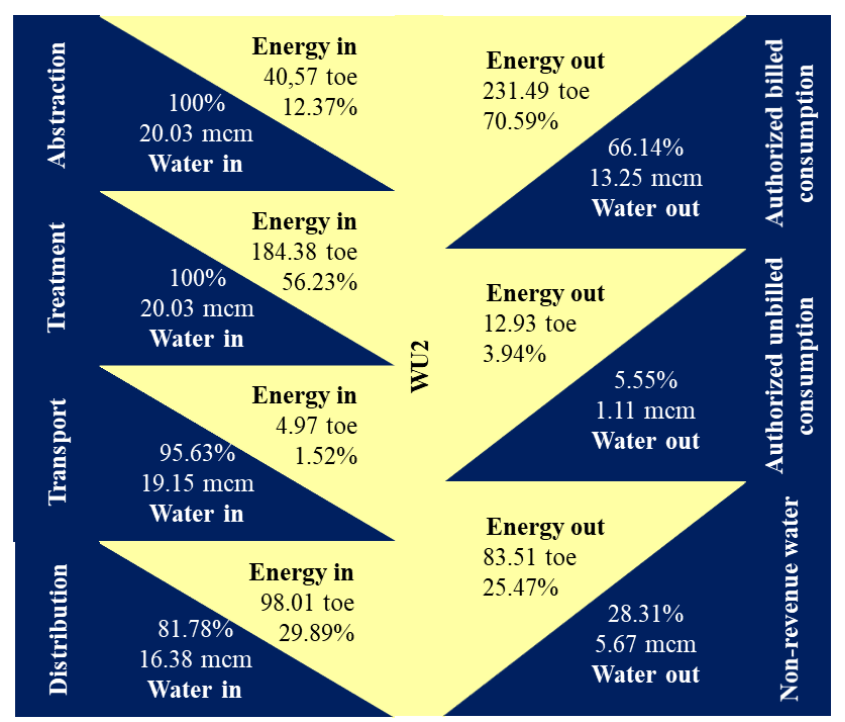

Fig. 7. Water-energy balance scheme - WU1 and WU2. 
This happens because energy is necessary at all stages of the clear water cycle. When losses occur at a certain point, only a proportional part of the energy inputs upstream that point will be lost with water losses occurring in that respective point.

The structure and characteristics of the water supply system also influences the level of specific energy lost with water losses in each process. Water supply systems with higher specific energy consumptions in the abstraction and treatment processes (in our case, WU1) are expected to have greater values for specific embedded energy lost with water losses occurring in the supply or transport phases than water supply systems with lower specific consumptions in the abstraction and treatment phases.

\section{Conclusions}

Water utilities imply different types of energy inputs for both water- and wastewater-related processes, as well as other types of consumptions associated with operational and administrative activities. In terms of energy efficiency, all these consumptions should be assessed, as sometimes the most promising opportunities, in terms of energy and cost reduction, can be found in other processes than the primary ones.

Energy lost with water losses depends heavily on the rate of water losses. Considering some water systems in Romania have water losses that represent more than $50 \%$ of total abstracted water, high energy reduction is expected by implementing a performant non-revenue water management.

Energy losses are also dependent on the point in the water system where the water losses occur. Considering the same volume of water lost, higher the amount of embedded energy will be lost closer to the end-use, with negative implications on both the energy bill and on the environment.

Although intensive research has been done on assessing the energy and technical efficiency of each process in water supply systems, future research should focus on integrated methods which can holistically approach all the processes in water supply systems and water utilities for a proper assessment of energy efficiency.

The authors would like to thank SC Elsaco Esco SRL for providing the data from the water utilities, whose contribution was crucial in writing this paper.

\section{References}

1. J. Daia, S. Wua, G. Hanb, J. Weinbergc, X. Xiea, X. Wua, X. Songd, B. Jiaa, W. Xuea, Q. Yanga, Appl. Energ. 210, $393 \quad$ (2018) DOI: 10.1016/j.apenergy.2017.08.243
2. K. James, S.L. Campbell, C.E. Godlove, Watergy: taking advantage of untapped energy and water efficiency opportunities in municipal water systems (Alliance to Save Energy, 2002)

3. OECD/IEA, Water Energy Nexus, Excerpt from the World Energy Outlook 2016 (IEA Publishing, 2016, Licence: www.iea.org/t\&c)

4. WWAP (United Nations World Water Assessment Programme), The United Nations World Water Development Report 2014: Water and Energy (UNESCO, Paris, 2014)

5. A. Mamade, C. Sousa, A. Marques, D. Loureiro, H. Alegre, D. Covas, Procedia Engineering 119, 1098 (2015) DOI: 10.1016/j.proeng.2015.08.944

6. N. Trifunovic, Introduction to Urban Water Distribution (Taylor and Francis, London, 2006)

7. C. van den Berg, Utilities Policy 36, 71 (2015) DOI: 10.1016/j.jup.2015.07.005

8. M. Khalkhali, K.Westphal, W. Mo, Sci. Total Environ. 636, $1257 \quad$ (2018) DOI: 10.1016/j.scitotenv.2018.04.408

9. E. Cabrera, M.A. Pardo, R. Cobacho, E. Cabrera Jr., Journal of Water Resources Planning and Management 136, Issue 6 (2010) DOI: 10.1061/(ASCE)WR.1943-5452.0000077

10. National Institute of Statistics (Romania), Romanian Statistical Yearbook (2017)

11. Autoritatea Naţională de Reglementare pentru Serviciile Comunitare de Utilităţi Publice - Raport de activitate (2013)

12. Autoritatea Națională de Reglementare pentru Serviciile Comunitare de Utilități Publice-Raport de activitate (2012)

13. Autoritatea Națională de Reglementare pentru Serviciile Comunitare de Utilități Publice-Raport de activitate (2016)

14. R. Pătraşcu, E. Minciuc, Calitatea: Acces la Succes 16, Issue 149, 25 (2015)

15. Autoritatea Naţională de Reglementare în domeniul Energiei, Raport de monitorizare a consumatorilor finali de energie pe anul 2016 (2017)

16. M.R. Teixeira, P. Mendes, E. Murta, L.M. Nunes, Journal of Cleaner Production 125, 108 (2016) DOI 10.1016/j.jclepro.2016.03.016

17. H. Alegre, J.M. Baptista, E. Cabrera Jr., F. Cubillo, P. Duarte, W. Hirner, W. Merkel, R. Parena, Performance indicators for water supply services second edition (IWA Publishing, 2006)

18. Asociația de Standardizare din România (ASRO), Alimentări cu apă - Determinarea cantităților de apă potabilă pentru localități urbane și rurale (SR 13431:2006) (2006) 